\title{
Review on Flos Arnicae: Phytochemical Screening, Chemical Constituents, and Pharmacological Applications
}

\author{
Khaled Mohamed Mohamed Koriem 1, * (D) \\ 1 Department of Medical Physiology, Medical Research Division, National Research Centre, 33 El-Buhouth Street, Dokki, \\ Cairo, 12622, Egypt \\ * Correspondence: kkoriem@yahoo.com (K.M.M.K.);
}

Scopus Author ID 24477156100

Received: 9.01.2021; Revised: 7.02.2021; Accepted: 9.02.2021; Published: 14.02.2021

\begin{abstract}
The dried flowers of Carthamus tinctorius L. (Asteraceae) is called Flos Arnicae. The other names of Flos Arnicae are Arnique, Arnika, betouana, mountain tobacco. This review aims to focus on phytochemical screening, chemical constituents, and pharmacological applications of Flos Arnicae. Carthamus tinctorius plant is indigenous to central Europe, but it is cultivated all over the world. The Carthamus tinctorius (safflower) is a perennial, branched and herbaceous. The main ingredients of Flos Arnicae include the essential oil (0.5\%), fatty acids, thymol, pseudoguaianolide sesquiterpene lactones $(0.2-0.8 \%)$, and flavonoid glycosides $(0.2-0.6 \%)$. It is applied in treating pain and inflammation from minor injuries and accidents such as bruises, ecchymosis, hematomas, and petechiae. Flos Arnicae treats cardiovascular disease, indigestion, and rheumatism, and it is also applied as an emmenagogue. The pharmacological effect of Flos Arnicae includes experimental and clinical pharmacology. Experimental pharmacology includes anti-inflammatory, antioxidant, anti-cancer, cardiovascular, choleretic, and uterine stimulant effects. Clinical pharmacology includes antianxiety, antidepressant, analgesic, antidiabetic, and anti-obesity effects. Flos Arnicae is used externally on the affected area 2 or 3 times/ day. In rabbits or mice, or rats, the Flos Arnicae is tested and found not toxic in acute toxicity studies. In mice and guinea pig skin, the Flos Arnicae is not irritating, sensitizing, or phototoxic. In 100 cosmetic preparations, the Flos Arnicae is found. There is not any significant ocular irritation after Flos Arnicae exposure. In conclusion, Flos Arnicae has anti-inflammatory, antioxidant, anti-cancer, cardiovascular, choleretic, uterine stimulant, antianxiety, antidepressant, analgesic, anti-diabetic, and anti-obesity effects.
\end{abstract}

Keywords: Flos Arnicae; Carthamus tinctorius; Asteraceae; pharmacology; toxicology; dose.

(C) 2021 by the authors. This article is an open-access article distributed under the terms and conditions of the Creative Commons Attribution (CC BY) license (https://creativecommons.org/licenses/by/4.0/).

\section{Introduction}

The dried flowers of Carthamus tinctorius L. (Asteraceae) are called Flos Arnicae [1,2]. Family Compositae is also called the Asteraceae family. The other names of Flos Arnicae are Arnique, Arnika, betouana, mountain tobacco [3-5]. Carthamus tinctorius plant is indigenous to central Europe, but it is cultivated worldwide [1,5]. The Carthamus tinctorius (safflower) is a perennial, branched and herbaceous. The plant is $30-150 \mathrm{~cm}$ tall, with globular flower heads having yellow, orange, or red flowers. Each branch has 1-5 flower heads and contains 15-20 seeds/head. Stress decreased chlorophyll- $a$, chlorophyll- $b$, total chlorophyll, carotenoid, relative water content, seed yield, and oil percentage. Superoxide dismutase activities, catalase, polyphenol oxidase, and proline contents increased in stress [6]. The safflower crops have been affected by parasitic plants and weeds. The sesquiterpene lactone dehydrocostuslactone 
ingredient of the plant is phytotoxic on 3 weeds (called Lolium perenne, Lolium rigidum Echinochloa crus-galli) [7]. Carthamus tinctorius aerial part consists of entire oblanceolate leaves up to $17 \mathrm{~cm}$ long, 5-7 veins, from the leaves center a simple, glandular-hairy stem up to $0.6 \mathrm{~m}$ high has occurred. Carthamus tinctorius stem possesses 2-4 pairs of cauline leaves, ovate, lanceolate, or oblanceolate, with a rounded apex and covered with many hairs $16 \mathrm{~cm}$ long and $5 \mathrm{~cm}$ wide. Carthamus tinctorius flowers are generally yellow, orange, and red. Carthamus tinctorius fruits, black to brown, 5 ribbed, possess bristle tuft of hairs [3]. Safflower is sensitive to elevation changes where the plant grows more in the mountainous regions at heights of 1,200 $\mathrm{m}$ above sea level. So, the factors affecting the distribution of microorganisms in safflower soils are soil moisture, available nitrogen, and above sea level [8]. The Flos Arnicae is $20 \mathrm{~mm}$ in diameter and $15 \mathrm{~mm}$ deep, with a peduncle $2-3 \mathrm{~cm}$ long. Involucre with 18-24 elongated lanceolate bracts, 8-10 $\mathrm{mm}$ long with acute apices, arranged in one or two rows, green with yellowish green external hairs visible under a lens. The receptacle, diameter= $6 \mathrm{~mm}$, is convex and covered with hairs. It is periphery possesses 20 ligulate florets (long=20$30 \mathrm{~mm}$ ); disc possesses a greater number of tubular florets (long = $15 \mathrm{~mm}$ long). Ovary (long= 4-8 $\mathrm{mm}$ ) capped with a pappus of whitish bristles (4-8 $\mathrm{mm}$ long) [2]. The safflower possesses volatiles that attracted the mirid bug than cotton. So, safflower has an effective trap crop for the mirid bug and controls the mirid bug in cotton [9]. The variation and symmetry of leaf miner control the safflower crop, where safflower possesses resistant variations to leaf miner and, consequently, high-efficiency pesticide. So, the integrated pest controls the leaf miner where leaf miner is one of the major pests on safflower, which causes yield loss and poor quality seriously [10]. The thermodynamic factors such as the change in Gibb's free energy, the difference in enthalpy, and the entropy change of safflower residues are $201.36 \mathrm{~kJ} / \mathrm{mol}$, $71.79 \mathrm{~kJ} / \mathrm{mol}$, and $-0.196 \mathrm{~kJ} / \mathrm{mol}$, respectively. The safflower residues contain high energycontaining compounds. So, safflower residues are suitable for pyrolysis to yield biofuel and chemicals [11]. Turkey safflower possesses a higher 100-seed weight compared to Pakistan safflower. The 3 safflower accessions (Egypt-5, Egypt-2, and India-2) have the highest genetic distance [12]. The safflower crop biorefinery consists of six units (straw handling, biomass pretreatment, bioethanol production, wastewater treatment, oil extraction, and biodiesel production). The huge amount of agro-wastes safflower originates from increasing agricultural activities, and these cause severe environmental and human health problems. The total exergetic efficiency of safflower stands at $72.7 \%$, indicating the suitability of developed biorefinery [13]. This review aims to focus on phytochemical screening, chemical constituents, and pharmacological applications of Flos Arnicae.

\section{Chemical constituents of Flos Arnicae}

The main ingredients of Flos Arnicae include the essential oil (0.5\%), fatty acids, thymol, pseudoguaianolide sesquiterpene lactones (0.2-0.8\%), and flavonoid glycosides (0.2$0.6 \%$ ) [14]. The primary sesquiterpene lactones are helenalin, 11 $\alpha, 13$-dihydrohelenalin, and their fatty acid esters. Flavonoids include glycosides and/or glucuronides of spinacetin, hispidulin, patuletin, and isorhamnetin, among others [5, 14-16]. Safflower contains 93 volatiles such as alcohols, aromatics, aldehydes, ketones, aliphatic hydrocarbons, mono-and sesquiterpenes, oxides/ethers, and pyrans/furans. The main ingredients are safranal, 2-caren10 -al, estragole, $\beta$-caryophyllene, and eugenol [17]. The main bioactive chemical constituents of Carthamus tinctorius include diterpene compounds, carthamin, polyphenolic acids, and hydroxysafflor yellow A [18]. There are 225,008 unigenes in safflower include 7 unigenes of 
phenylalanine ammonia-lyase, 20 unigenes of 4-coumarate-CoA ligase, 1 unigene of transcinnamate 4-monooxygenase, 7 unigenes of chalcone synthase, 4 unigenes of chalcone isomerase, and 1 unigene of flavanone 3-hydroxylase [19]. There are a new alkaloid and a new glucopyranoside isolated from safflower [20]. Another neo-complanatoside and neo-carthamin are identified in Carthamus tinctorius [21]. Flos Arnicae contains 5 ingredients; quercetin, chlorogenic acid, quinic acid, hyperoside, and rutin [22]. Carthamus tinctorius plant possesses 2 dihydrophaseic acid glucosides (1 and 2) [23]. The flavonoids are the active ingredients in Carthamus tinctorius L [24].

\section{Flos Arnicae in traditional medicine}

Flos Arnicae is applied as an anti-inflammatory agent in traditional Brazilian medicine [22]. It is applied in treating pain and inflammation from minor injuries and accidents such as bruises, ecchymosis, hematomas, and petechiae [1, 25]. Carthamus tinctorius plant has been applied in Korean traditional medicine for sustaining the homeostasis of body circulation [23]. Carthamus tinctorius is a classic Chinese medicine remedy for treating cerebral ischemia and gynecological diseases [24]. Flos Arnicae treats the oral mucous membranes' inflammation, insect bites, and superficial phlebitis [25]. Flos Arnicae treats cardiovascular disease, indigestion, and rheumatism, and it is also applied as an emmenagogue [25]. Carthamus tinctorius is applied in folklore medicine as an analgesic, antipyretic, purgative, and a remedy for poisoning. It is an appropriate plant for osteoporosis, post-partum hemorrhage, and painful menstrual problems [26].

\section{Pharmacological effect of Flos Arnicae}

\subsection{Experimental pharmacology.}

\subsubsection{Anti-inflammatory effect.}

The feruloyl serotonin ingredient in safflower seeds possesses anti-inflammatory activity [27]. The moschamine ingredient of Carthamus tinctorius L. has an anti-inflammatory effect through declines lipopolysaccharide-induced production of prostaglandin $\mathrm{E}_{2}$ and nitric oxide. The moschamine declines the protein and mRNA levels of cyclooxygenase-2, microsomal prostaglandin $\mathrm{E}_{2}$ synthase-1, and inducible NO synthase, interleukin-6, interleukin-1 $\beta$ [28]. The intake of $2.5-5 \mathrm{mg} / \mathrm{kg}$ bw of helenalin (an anti-inflammatory sesquiterpene lactone from Flos Arnicae) declines hind paw edema by $77 \%$ following 72 hours. The intake of $20 \mathrm{mg} / \mathrm{kg}$ bw of helenalin declines writhing by $93 \%$ but without analgesic effects in the hot-plate test. The administration of $2.5 \mathrm{mg} / \mathrm{kg}$ bw of helenalin declines arthritis by $87 \%$ [29]. The helenalin inhibits activation of transcription factor nuclear factor (NF-kappaB) by molecular mechanism [30]. The 11 alpha,13-dihydrohelenalin ingredient is the principal sesquiterpene lactones and possesses anti-inflammatory activity in the Spanish flowers Flos Arnicae [31]. Chamisso Flos Arnicae possesses anti-inflammatory and antiradical activity [32]. The hydroxysafflor yellow A (a major ingredient of Carthamus tinctorius) declines the levels of tumor necrosis factor- $\alpha$ and the inflammatory products such as free fatty acids and lactic dehydrogenase [33]. 


\subsubsection{Antioxidant effect.}

Arnica has an antioxidant effect, which possesses a similar wound healing effect to the Recoveron ${ }^{\circledR}$ drug, but with a higher healing rate, so the treatment of Flos Arnicae increases the remodeling phase 15 days following the incisional wound [34]. Chamisso Flos Arnicae possesses high antioxidant activity, which prevents and delays the progress of free radical dependent diseases [32]. The feruloyl serotonin ingredient in safflower seeds possesses antioxidant activity [27]. Flos Arnicae possesses high antioxidant content, and consequently, Flos Arnicae has anti-aging activity [35]. The safflor yellow A and hydroxy safflor yellow A ingredients of Carthamus tinctorius have high antioxidant activity. Both Carthamus tinctorius ingredients can decline the low-density lipoprotein that caused lipid peroxidation [36]. An antioxidant effect is established for safflower oil, so safflower oil is a good natural remedy for skin wounds [37-39]. The safflower ingredients (hydroxysafflor yellow A and anhydrosafflor yellow B) reveal good antioxidant activity, and so safflower ingredients encourage the application of these 2 ingredients on cardiovascular and cerebrovascular disease treatment [40]. The safflower seed extract and its oil recover fructose-induced metabolic syndrome through antioxidant and anti-inflammatory effects and increase the $\beta$-oxidation activity of the liver [41]. The hydroxysafflor yellow A isolates from the Chinese herb Carthamus tinctorius L. improve antioxidant status through the activity of superoxide dismutase, catalase, glutathione peroxidase, and malondialdehyde, so hydroxysafflor yellow A improves the aging changes such as body weight and organ index [42].

\subsubsection{Anti-cancer effect.}

The Mexican Flos Arnicae is applied in traditional Mexican medicine as an anti-cancer therapy. The sesquiterpenes ingredient of Mexican Flos Arnicae possesses the highest anticancer activity. The 7-hydroxy-3,4-dihydrocadalene ingredient of Mexican arnica possesses anti-cancer activity at very high doses [43]. The safflower seeds have cytotoxicity against hepatocarcinoma cell line and possess hepato-protection against Non-alcoholic fatty liver disease. Also, safflower seeds improve the liver biochemical parameters [44]. The safflower seed is highly toxic to cell-derived human colorectal tumors and inhibits tumor growth in cisplatin-treated mice through renoprotective effects where safflower declines serum creatinine and consequently leads to decrease the damage of the kidney, and decreases solid tumor mass, and increases expression of the caspase-3 protein [45]. The safflower possesses the highest activity as an anti-cancer agent, so safflower possesses high activity as antimicrobial, antioxidant, and anti-cancer agents [46]. The hydroxysafflor yellow A (an ingredient of Carthamus tinctorius) declines the hepatocellular carcinoma HepG2 cell viability, proliferation, and migration. The hydroxysafflor yellow A causes apoptosis of hepatocellular carcinoma HepG2 cells, so hydroxysafflor yellow A has anti-cancer activity for hepatocellular carcinoma [47].

\subsubsection{Cardiovascular effect.}

The safflower (Carthamus tinctorius. L.) is widely applied to treat cardiovascular and cerebrovascular diseases due to safflower flavonoids ingredients [48]. The safflower ameliorates myocardial ischemia-disturbed antioxidant and prooxidative metabolites and inhibits oxidative stress. So, safflower increases the anti- myocardial ischemia activity, which is applied for the clinical application [49]. The hydroxysafflor yellow A (a major ingredient of 
Carthamus tinctorius) is applied to treat cardiovascular diseases due to its property of increasing blood circulation and removing blood stasis. The hydroxysafflor yellow A applies due to its vessel dilation effect on rat mesenteric artery, and consequently, hydroxysafflor yellow A is applied for the treatment of hypertension [50]. Safflower is used in the treatment of myocardial infarction, and consequently, safflower is applied in the treatment of cardiocerebrovascular diseases [51]. Carthamus tinctorius extract prevents cardiomyoblast cell hypertrophy and decreases hypertrophic proteins calcineurin [52]. Carthamus tinctorius L. lowered the rat's heart weight/body weight and left ventricular mean/body weight, and the level of B-type natriuretic peptide, so Carthamus tinctorius inhibits myocardial fibrosis in heart failure rats. The cardiac protective of Carthamus tinctorius due to inhibiting cardiac fibrosis and attenuates apoptosis [53]. Carthamus tinctorius is more effective in treating cerebral ischemia, and Carthamus tinctorius affects target sites in the brain to protect against cerebral ischemic injury [54].

\subsubsection{Choleretic effect.}

The intake of $1.0 \mathrm{ml}$ of a $95 \%$ ethanol extract of Flos Arnicae increases the bile secretion by $25-120 \%$ [55]. The intake of water extract of Flos Arnicae has choleretic effects in rats [56] and dogs (50 ml/animal) [57]. The ileum delivers safflower oil, which declines food intake appetite through the increase of the ileal brake. The safflower oil affects satiety and food intake. The unsaturated fatty acids and triacylglycerols increase satiety while saturated fatty acids and triacylglycerols do not [58]. After liquid breakfast, the postprandial satiety increases slightly (as little as $3 \mathrm{~g}$ ) of safflower oil perfused into the ileum [59].

\subsubsection{Uterine stimulant effect.}

The safflower yellow (the main ingredient of safflower) protects chondrocytes and inhibits inflammation by regulating the nuclear factors pathways and endoplasmic reticulum stress, so preventing cartilage degeneration in osteoarthritis [60]. The hydroxysafflor yellow A (the main ingredient of safflower) is applied as a potential therapeutic agent in osteoarthritis treatment. The hydroxysafflor yellow A attenuates interleukin-1 $\beta$-induced breakdown of the extracellular matrix by decreasing the expression of thrombospondin motifs 5 and metalloproteinases. The hydroxysafflor yellow A suppresses the interleukin-1 $\beta$-induced increase of the mitogen-activated protein kinase and nuclear factor kappa B [61].

\subsection{Clinical pharmacology.}

\subsubsection{Antianxiety and antidepressant effects}

Carthamus tinctorius possesses an anxiolytic effect. It increases the latency of first entry to closed arms and the time spent in open arms while entries to open arms increase and increase immobility. So, Carthamus tinctorius is used as a healing factor to treat patients with depressive and anxiety disturbances [62]. The safflower oil affects the high alphalinolenate/high linoleate ratio of brain phospholipid acyl chains, and that this is associated with general behavioral characters [63]. The coumaroylspermidine extract from safflower has an antidepressant effect. This extract inhibits the increase in corticosterone levels and decreases the levels of 5-hydroxytryptamine, dopamine, and noradrenaline [64]. Safflower improves stress-induced depressed syndromes in the stressed rats by controlling luteinizing hormone and 
follicle-stimulating hormone levels and norepinephrine, dopamine, serotonin, and cortisone levels [65]. The N-Hexadecanoic acid ingredient of Carthamus tinctorius L. causes an antidepressant-like effect by interaction with dopaminergic receptors (D1 and D2) and serotonergic receptors (5HT1A and 5-HT2A) systems. So, Carthamus tinctorius L. is applied for the treatment of depression [66].

\subsubsection{Analgesic effect.}

The dose of 100 and $300 \mathrm{mg} / \mathrm{kg}$ of safflower oil has an analgesic effect. So, safflower oil possesses analgesic-anti-inflammatory treatment that can be used for the treatment of postoperative pain and inflammation [67]. The feruloyl serotonin is hydroxycinnamic acid amides of serotonin and exists in safflower seeds. The feruloyl serotonin has analgesic, antioxidative, and anti-inflammatory effects. Thus, feruloyl serotonin is applied as an agent to inhibit epidermal inflammation due to its anti-inflammatory and anti-oxidative effects [27]. Flos Arnicae improves 2 patients with breast cancer and severe liver disease patients' overall condition without the need for other common pain-relieving medicines. The patients, thanks to their quick awakening, were not relocated to a protected area, and the hospitalization was shorter. So, Flos Arnicae provides a safe and less expensive for these patients and be useful for opioid-free anesthesia [68]. The helenalin (an active ingredient of Flos Arnicae) has strong anti-inflammatory activity, and consequently, it is used to treat minor injuries. So, helenalin is applied as an anti-cancer or anti-inflammatory drug due to its analgesic effect [69]. Flos Arnicae and curcumin possess good anti-osteoarthritic and analgesic activity for the treatment of osteoarthritis [70]. The analgesic effect of Flos Arnicae is similar to the effect of Cupressus sempervirens [71]. Flos Arnicae ointment is active in relieving the auricular inflammatory process and oxidative damage induced by acute ultraviolet radiation, sustaining the traditional use of Flos Arnicae to treat skin disturbances [72].

\subsubsection{Anti-diabetic effect.}

The Flos Arnicae contains the highest contents of carotenoids and triterpenoids. So, Flos Arnicae inhibits $\alpha$-glucosidase, which enables the Arnica to possess anti-diabetic and anticholinergic Effects [35]. The Carthamus tinctorius decreases fasting blood glucose, triglyceride, cholesterol, low-density lipoproteins, and very-low-density lipoproteins. Carthamus tinctorius L increases insulin secretion. So, Carthamus tinctorius possesses a principal role in diabetic cure [73]. The safflower contains Chalcone ingredients with antidiabetic, antimicrobial, antioxidant, anti-cancer, anti-amyloid, anti-inflammatory, and antiobesity, hypolipidemic, and cytoprotective effects [74]. Hydroxysafflor yellow A (the main ingredient of Carthamus tinctorius L.) declines fasting-blood glucose and insulin resistance in type 2 diabetes mellitus. Hydroxysafflor yellow A inhibits the apoptosis of pancreatic $\beta$-cells. It increases glycogen synthase and hepatic glycogen levels. It improves lipid metabolism by decline the triglyceride, total and low-density lipoprotein levels [75]. Safflower Yellow (the main ingredient of Carthamus tinctorius L.) declines the fasting blood glucose and increase insulin sensitivity and body fat. So, safflower yellow is applied as an anti-diabetic and antiobesity remedy [76]. 


\subsubsection{Anti-obesity effect.}

The safflower oil recovers obesity-induced increases in body weight, liver weight, and epididymal fat weight. It declines abdominal fat volume and decreases serum triglyceride and leptin levels. It increases adiponectin levels. So, safflower oil has an anti-obesity effect [77]. Both hydroxysafflor yellow A and yellow safflower decline the body weight. The hydroxysafflor yellow A and safflower yellow improve liver function and glucose metabolism. So, hydroxysafflor yellow A and yellow safflower decline the fat mass index and improve liver function and glucose metabolism in diet-induced obese. These effects of hydroxysafflor yellow A and safflower yellow are correlated with the increase of expression of antioxidant enzymes in adipose tissue and liver [78]. In another study, the safflower yellow A declines serum glucose levels and fat mass index. The safflower yellow A recovers insulin sensitivity in obesity. It increases the genes of the mRNA levels of insulin signaling path in subcutaneous adipose tissue [79]. The oral intakes of hydroxysafflor yellow A decline high-fat diet-induced obesity. It declines fat increase, improves insulin resistance, restores glucose homeostasis, declines inflammation, increases intestinal integrity, and increases short-chain fatty acids production in a high-fat diet [80].

\section{Toxicology of Flos Arnicae}

The oral median lethal dose (LD50) of Flos Arnicae is $37 \mathrm{ml} / \mathrm{kg}$ in mice [81]. The injection $\mathrm{LD}_{50}$ dose for helenalin (the main ingredient of Flos Arnicae) are; for mice $150 \mathrm{mg} / \mathrm{kg}$ bw, for rats $125 \mathrm{mg} / \mathrm{kg} \mathrm{bw}$, for rabbits $90 \mathrm{mg} / \mathrm{kg} \mathrm{bw}$, for hamsters $85 \mathrm{mg} / \mathrm{kg} \mathrm{bw}$, and ewes 125 $\mathrm{mg} / \mathrm{kg}$ bw [82]. In rabbits, mice, or rats, the Flos Arnicae was tested and found not toxic in acute toxicity studies. In mice and guinea pig skin, the Flos Arnicae is not irritating, sensitizing, or phototoxic. Flos Arnicae is found in 100 cosmetic preparations. There is no significant ocular irritation due to the Flos Arnicae exposure [83].

\section{Adverse effects of Flos Arnicae}

Many cases of allergic conditions are found following prolonged application of Flos Arnicae [84]. This allergy is related to the sesquiterpene lactones helenalin and helenalin acetate [85]. The clinical investigation of Arnika reveals that it is applied in treating rheumatic diseases but has undesirable side effects such as allergy and hypersensitivity [86]. The safflor yellow A, hydroxysafflor yellow A, and anhydrosafflor yellow B are 3 major ingredients of safflower that possess a protective effect against lipopolysaccharide-induced lung damage and neutrophil extracellular traps discharge [87]. The Carthamus tinctorius possesses a clinical remedy in isoproterenol-induced acute myocardial ischemia [88]. The safflower oil sustains the highest conjugated linoleic acid in sausages without any adverse effects on the quality of the final sausage product [89]. The Flos Arnicae is irritant to the mucous membranes, and Arnika ingestion causes an increase in pulse rate. The ingestion of $70 \mathrm{~g}$ of Flos Arnicae causes a case of poisoning [90]. A mucosal injury has occurred after 70\% Flos Arnicae extract [91].

\section{Contraindications of Flos Arnicae}

Flos Arnicae treats cardiovascular disease, indigestion, and rheumatism. It is also applied as an emmenagogue [25], and it is safe during pregnancy. Flos Arnicae side effects 
include allergy [86]. Flos Arnicae is the most applied mediation in the postoperative setting, which fellow the American Board of Naturopathic Oncology [92].

\section{Precautions of Flos Arnicae}

\subsection{General precautions.}

The person must avoid extreme use of Flos Arnicae. The external applications may induce allergy-related skin associated with itching and superficial necrosis. The continued treatment of injured skin or indolent leg ulcers may cause the formation of edematous dermatitis with the formation of abscesses [25].

\subsection{Carcinogenesis, mutagenesis and impairment of fertility.}

In in vitro studies, helenalin possesses a cytotoxic effect. The helenalin is not mutagenic in Salmonella typhimurium strains TA102, TA98 and TA100 up to concentration $=30 \mu \mathrm{g} / \mathrm{ml}$ $[93,94]$. The anti-genotoxicity of Flos Arnicae is similar to that of anise oil [95]. The methanol and chloroform extracts of Carthamus tinctorius have a cytotoxic effect, but the water extract is not cytotoxic. On the other hand, the water extract of Carthamus tinctorius has more mutagenic effect than the chloroform and methanol extracts [96]. The Brazilian arnica has a protective influence on the process of colon carcinogenesis, suppressing both the initiation and the promotion of colonic carcinogenesis [97].

\subsection{Pregnancy and teratogenic effects.}

The injection of $6.0-20.0 \mathrm{mg} / \mathrm{kg}$ bw of helenalin is not teratogenic in mice [98]. The safflower oil decreases the rate of embryo malformations and increases their size and maturation $[99,100]$.

\subsection{Nursing mothers.}

Flos Arnicae safety during pregnancy and nursing has not been studied yet. Therefore, following ordinary medical guidelines, the Flos Arnika should not be administered to pregnant or nursing women. It is applied as external cream only.

\subsection{Paediatric use.}

In Flos Arnicae external use only, do not apply to abraded or broken skin.

\subsection{Other precautions.}

There is no information available on precautions concerning drug interactions; or drug and laboratory test interactions.

\section{Dose of Flos Arnicae}

Flos Arnicae must store away from light and water [5]. For external applications only, apply undiluted externally on the affected area 2 or 3 times/ day: infusion for compresses, $2 \mathrm{~g}$ of Flos Arnicae/ $100 \mathrm{ml}$ water; mixture for compresses, 1 part Flos Arnicae to 10 parts $70 \%$ ethanol; mouth rinse, a 10-fold dilution of the mixture, do not swallow; ointment, 20-25\% mixture of Flos Arnicae [25]. 


\section{Conclusion}

The dried flowers of Carthamus tinctorius L. (Asteraceae) are called Flos Arnicae. Carthamus tinctorius plant is indigenous to central Europe, but it is cultivated all over the world. The main ingredients of Flos Arnicae include the essential oil (0.5\%), fatty acids, thymol, pseudoguaianolide sesquiterpene lactones (0.2-0.8\%), and flavonoid glycosides (0.2$0.6 \%)$. Flos Arnicae is applied to treat pain and inflammation from minor injuries and accidents such as bruises, ecchymosis, hematomas, and petechiae. The pharmacological effect of Flos Arnicae includes experimental and clinical pharmacology. Flos Arnicae is used externally on the affected area 2 or 3 times/ day. In conclusion, Flos Arnicae has anti-inflammatory, antioxidant, anti-cancer, cardiovascular, choleretic, uterine stimulant, antianxiety, antidepressant, analgesic, anti-diabetic, and anti-obesity effects.

\section{Funding}

This review received no external funding.

\section{Acknowledgments}

This research has no acknowledgment.

\section{Conflict of interest}

The author declares no conflict of interest.

\section{References}

1. British herbal pharmacopoeia. Exeter, British Herbal Medicine Association, 1996.

2. European pharmacopoeia, 3rd ed. Suppl. 2001. Strasbourg, Council of Europe, 2000.

3. Youngken, H.W. Textbook of pharmacognosy. 6th edition. The Blakiston Company. Philadelphia, 1948, Journal of the American Pharmaceutical Association 1949, https://doi.org/10.1002/jps.3030380525.

4. Zahedi, E. Botanical Dictionary: Scientific Names of Plants in English, French, German, Arabic and Persian Languages. Teheran: University Press: 1959.

5. Bisset, N.G. Herbal drugs and phytopharmaceuticals; CRC: 1994.

6. Zafari, M.; Ebadi, A.; Jahanbakhsh, S.; Sedghi, M. Safflower (Carthamus tinctorius) Biochemical Properties, Yield, and Oil Content Affected by 24-Epibrassinosteroid and Genotype under Drought Stress. Journal of Agricultural and Food Chemistry 2020, 68, 6040-6047, http://doi.org/10.1021/acs.jafc.9b06860.

7. Rial, C.; Tomé, S.; Varela, R.M.; Molinillo, J.M.G.; Macías, F.A. Phytochemical Study of Safflower Roots (Carthamus tinctorius) on the Induction of Parasitic Plant Germination and Weed Control. Journal of Chemical Ecology 2020, 46, 871-880, http://doi.org/10.1007/s10886-020-01200-7.

8. Liu, Y.; Zhang, X.; Yang, M.L.; Wang, S.M. Study on the correlation between soil microbial diversity and ambient environmental factors influencing the safflower distribution in Xinjiang. Journal of Basic Microbiology 2020, 60, 517-531, http://doi.org/10.1002/jobm.201900626.

9. Wang, W.; Zhang, R.; Liu, H.; Tian, J.; Shelton, A.M.; Yao, J. Use of safflower as a trap crop for managing the mirid bug, Lygus pratensis Linnaeus (Hemiptera: Miridae), in cotton fields. Pest Management Science 2020, http://doi.org/10.1002/ps.6208.

10. Xu, L.J.; Liang, H.Z.; Nie, Z.S. [Study on the Occurrence Regularity and Integrated Control Techniques of Safflower Leaf Miner]. Zhongguo Zhong Yao Za Zhi= Chinese Journal of Traditional Chinese Medicine 2020, 45, 2835-2841, http://doi.org/10.19540/j.cnki.cjcmm.20200329.104.

11. Tahir, M.H.; Mahmood, M.A.; Çakman, G.; Ceylan, S. Pyrolysis of oil extracted safflower seeds: Product evaluation, kinetic and thermodynamic studies. Bioresour. Technol. 2020, 314, 123699, http://doi.org/10.1016/j.biortech.2020.123699. 
12. Ali, F.; Nadeem, M.A.; Barut, M.; Habyarimana, E.; Chaudhary, H.J.; Khalil, I.H.; Alsaleh, A.; Hatipoğlu, R.; Karaköy, T.; Kurt, C.; Aasim, M.; Sameeullah, M.; Ludidi, N.; Yang, S.H.; Chung, G.; Baloch, F.S. Genetic Diversity, Population Structure and Marker-Trait Association for 100-Seed Weight in International Safflower Panel Using SilicoDArT Marker Information. Plants 2020, 9, http://doi.org/10.3390/plants9050652.

13. Khounani, Z.; Hosseinzadeh-Bandbafha, H.; Nazemi, F.; Shaeifi, M.; Karimi, K.; Tabatabaei, M.; Aghbashlo, M.; Lam, S.S. Exergy analysis of a whole-crop safflower biorefinery: A step towards reducing agricultural wastes in a sustainable manner. J. Environ. Manage. 2021, 279, 111822 , http://doi.org/10.1016/j.jenvman.2020.111822.

14. Bruneton, J. Pharmacognosy, phytochemistry, medicinal plants; Lavoisier publishing: 1995.

15. Merfort, I.; Wendisch, D. New flavonoid glycosides from Arnicae flos DAB 91. Planta Med. 1992, 58, 355357.

16. Merfort, I.; Wendisch, D. Flavonoid Glucuronides from the Flowers of Arnica montana1. Planta Med. 1988, 54, 247-250.

17. Farag, M.A.; Hegazi, N.; Dokhalahy, E.; Khattab, A.R. Chemometrics based GC-MS aroma profiling for revealing freshness, origin and roasting indices in saffron spice and its adulteration. Food Chem. 2020, 331, 127358, http://doi.org/10.1016/j.foodchem.2020.127358.

18. Orgah, J.O.; He, S.; Wang, Y.; Jiang, M.; Wang, Y.; Orgah, E.A.; Duan, Y.; Zhao, B.; Zhang, B.; Han, J.; Zhu, Y. Pharmacological potential of the combination of Salvia miltiorrhiza (Danshen) and Carthamus tinctorius (Honghua) for diabetes mellitus and its cardiovascular complications. Pharmacol. Res. 2020, 153, 104654, http://doi.org/10.1016/j.phrs.2020.104654.

19. Qiang, T.; Liu, J.; Dong, Y.; Ma, Y.; Zhang, B.; Wei, X.; Liu, H.; Xiao, P. Transcriptome Sequencing and Chemical Analysis Reveal the Formation Mechanism of White Florets in Carthamus tinctorius L. Plants 2020, 9, http://doi.org/10.3390/plants9070847.

20. Huang, X.-X.; Yan, Z.-Y.; Liu, S.; Wang, X.-B.; Song, S.-J. Investigation of chemical constituents of safflower and their tyrosinase inhibitory activity. J. Asian Nat. Prod. Res. 2019, 21, 248-256, http://doi.org/10.1080/10286020.2018.1430775.

21. Gu, Y.; Zhao, B.W.; Chen, X.; Luo, Y.Z.; Zhang, Y.L. [Multi-target neuroprotective effect of Xixian Tongshuan preparation against cerebral ischemia injury]. Zhongguo Zhong Yao Za Zhi= Chinese Journal of Traditional Chinese Medicine 2019, 44, 2353-2358, http://doi.org/10.19540/j.cnki.cjcmm.20190111.006.

22. Vogas, R.S.; Pereira, M.; Duarte, L.S.; Carneiro, M.J.; Farsura, A.F.; Machado, J.A.M.M.; Costa, I.F.; Tome, M.; Milton, F.A.; Neves, F.A.R. Evaluation of the anti-inflammatory potential of Solidago microglossa (Arnica-brasileira) in vivo and its effects on PPAR $\gamma$ activity. An. Acad. Bras. Cienc. 2020, 92, http://doi.org/10.1590/0001-3765202020191201.

23. Baek, S.C.; Lee, B.S.; Yi, S.A.; Yu, J.S.; Lee, J.; Ko, Y.-J.; Pang, C.; Kim, K.H. Discovery of Dihydrophaseic Acid Glucosides from the Florets of Carthamus tinctorius. Plants 2020, 9, http://doi.org/10.3390/plants9070858.

24. Duan, X.; Pan, L.; Peng, D.; Bao, Q.; Xiao, L.; Zhou, A.; Wu, H.; Peng, C.; Chen, W. Analysis of the active components and metabolites of Taohong Siwu decoction by using ultra high performance liquid chromatography quadrupole time-of-flight mass spectrometry. J. Sep. Sci. 2020, 43, 4131-4147, http://doi.org/10.1002/jssc.202000498.

25. Blumenthal, M.; Busse, W.R. Goldberg A, Gruenwald J, Hall T, Riggins CW, eds. The complete German commission E monographs: Therapeutic guide to herbal medicines. Austin, TX: American Botanical Council 1998.

26. Turgumbayeva, A.A.; Ustenova, G.O.; Yeskalieva, B.K.; Ramazanova, B.A.; Rahimov, K.D.; Aisa, H.; Juszkiewicz, K.T. Volatile oil composition of Carthamus Tinctorius L. flowers grown in Kazakhstan. Ann. Agric. Environ. Med. 2018, 25, 87-89, http://doi.org/10.5604/12321966.1235170.

27. He, Y.; Kim, B.-g.; Kim, H.-E.; Sun, Q.; Shi, S.; Ma, G.; Kim, Y.; Kim, O.-s.; Kim, O.-j. The Protective Role of Feruloylserotonin in LPS-Induced HaCaT Cells. Molecules 2019, 24, http://doi.org/10.3390/molecules24173064.

28. Jo, A.r.; Han, H.-s.; Seo, S.; Shin, J.-S.; Lee, J.Y.; Kim, H.J.; Lee, K.-T. Inhibitory effect of moschamine isolated from Carthamus tinctorius on LPS-induced inflammatory mediators via AP-1 and STAT1/3 inactivation in RAW 264.7 macrophages. Bioorg. Med. Chem. Lett. 2017, 27, 5245-5251, http://doi.org/10.1016/j.bmcl.2017.10.035. 
29. Asima, C.; Chandra, P.S. The treatise on indian medicinal plants. National Institute of Science Communication: 1997.

30. Lyss, G.; Schmidt, T.J.; Merfort, I.; Pahl, H.L. Helenalin, an Anti-Inflammatory Sesquiterpene Lactone from Arnica, Selectively Inhibits Transcription Factor NF-кB. Biol. Chem. 1997, 378, 951-962, http://doi.org/10.1515/bchm.1997.378.9.951.

31. Klaas, C.A.; Wagner, G.; Laufer, S.; Sosa, S.; Della Loggia, R.; Bomme, U.; Pahl, H.L.; Merfort, I. Studies on the anti-inflammatory activity of phytopharmaceuticals prepared from Arnica flowers. Planta Med. 2002, 68, 385-391, http://doi.org/10.1055/s-2002-32067.

32. Sugier, D.; Olesińska, K.; Sugier, P.; Wójcik, M. Chemical Composition of Essential Oil from Flower Heads of Arnica Chamissonis Less. under a Nitrogen Impact. Molecules 2019, 24, http://doi.org/10.3390/molecules24244454.

33. Lee, M.; Zhao, H.; Liu, X.; Liu, D.; Chen, J.; Li, Z.; Chu, S.; Kou, X.; Liao, S.; Deng, Y.; Li, H.; Xie, W. Protective effect of hydroxysafflor yellow A on nephropathy by attenuating oxidative stress and inhibiting apoptosis in induced type 2 diabetes in rat. Oxid Med Cell Longev 2020, 2020, 7805393, http://doi.org/10.1155/2020/7805393.

34. García-Bores, A.M.; Álvarez-Santos, N.; López-Villafranco, M.E.; Jácquez-Ríos, M.P.; Aguilar-Rodríguez, S.; Grego-Valencia, D.; Espinosa-González, A.M.; Estrella-Parra, E.A.; Hernández-Delgado, C.T.; SerranoParrales, R.; González-Valle, M.d.R.; Benítez-Flores, J.d.C. Verbesina crocata: A pharmacognostic study for the treatment of wound healing. Saudi J. Biol. Sci. 2020, 27, 3113-3124, http://doi.org/10.1016/j.sjbs.2020.08.038.

35. Nowicka, P.; Wojdyło, A. Anti-Hyperglycemic and Anticholinergic Effects of Natural Antioxidant Contents in Edible Flowers. Antioxidants 2019, 8, http://doi.org/10.3390/antiox8080308.

36. Bacchetti, T.; Morresi, C.; Bellachioma, L.; Ferretti, G. Antioxidant and Pro-Oxidant Properties of Carthamus Tinctorius, Hydroxy Safflor Yellow A, and Safflor Yellow A. Antioxidants 2020, 9, http://doi.org/10.3390/antiox9020119.

37. Khémiri, I.; Essghaier, B.; Sadfi-Zouaoui, N.; Bitri, L. Antioxidant and Antimicrobial Potentials of Seed Oil from Carthamus tinctorius L. in the Management of Skin Injuries. Oxid. Med. Cell. Longev. 2020, 2020, 4103418, http://doi.org/10.1155/2020/4103418.

38. Goodarzi, A.; Namdjoyan, S.; Soorki, A.A. Effects of exogenous melatonin and glutathione on zinc toxicity in safflower (Carthamus tinctorius L.) seedlings. Ecotoxicol. Environ. Saf. 2020, 201, 110853, http://doi.org/10.1016/j.ecoenv.2020.110853.

39. Namdjoyan, S.; Soorki, A.A.; Elyasi, N.; Kazemi, N.; Simaei, M. Melatonin alleviates lead-induced oxidative damage in safflower (Carthamus tinctorius L.) seedlings. Ecotoxicology 2020, 29, 108-118, http://doi.org/10.1007/s10646-019-02136-9.

40. Zhang, Y.; Yu, L.; Jin, W.; Li, C.; Wang, Y.; Wan, H.; Yang, J. Simultaneous Optimization of the Ultrasonic Extraction Method and Determination of the Antioxidant Activities of Hydroxysafflor Yellow A and Anhydrosafflor Yellow B from Safflower Using a Response Surface Methodology. Molecules 2020, 25, http://doi.org/10.3390/molecules25051226.

41. Nimrouzi, M.; Ruyvaran, M.; Zamani, A.; Nasiri, K.; Akbari, A. Oil and extract of safflower seed improve fructose induced metabolic syndrome through modulating the homeostasis of trace elements, TNF- $\alpha$ and fatty acids metabolism. J. Ethnopharmacol. 2020, 254, 112721, http://doi.org/10.1016/j.jep.2020.112721.

42. Min, F.; Sun, H.; Wang, B.; Ahmad, N.; Guo, H.; Gao, H.; Gao, Y.; Liu, X.; Li, H. Hepatoprotective effects of hydroxysafflor yellow A in D-galactose-treated aging mice. Eur. J. Pharmacol. 2020, 881, 173214, http://doi.org/10.1016/j.ejphar.2020.173214.

43. Rodríguez-Chávez, J.L.; Coballase-Urrutia, E.; Sicilia-Argumedo, G.; Ramírez-Apan, T.; Delgado, G. Toxicological evaluation of the natural products and some semisynthetic derivatives of Heterotheca inuloides Cass (Asteraceae). J. Ethnopharmacol. 2015, 175, 256-265, http://doi.org/10.1016/j.jep.2015.08.055.

44. Mohamed, D.A.; Fouda, K.A.; Mohamed, R.S. In vitro Anti-cancer Activity of Quinoa and Safflower Seeds and Their Preventive Effects on Non-alcoholic Fatty Liver. Pakistan journal of biological sciences: PJBS 2019, 22, 383-392, http://doi.org/10.3923/pjbs.2019.383.392.

45. Park, C.H.; Kim, M.J.; Yang, C.Y.; Yokozawa, T.; Shin, Y.S. Safflower seed extract synergizes the therapeutic effect of cisplatin and reduces cisplatin-induced nephrotoxicity in human colorectal carcinoma RKO cells and RKO-transplanted mice. Drug Discov. Ther. 2019, 13, 328-334, http://doi.org/10.5582/ddt.2019.01086. 
46. Ibrahim, F.Y.; El-Khateeb, A.Y.; Mohamed, A.H. Rhus and Safflower Extracts as Potential Novel Food Antioxidant, Anticancer, and Antimicrobial Agents Using Nanotechnology. Foods 2019, 8, http://doi.org/10.3390/foods8040139.

47. Zhang, J.; Li, J.; Song, H.; Xiong, Y.; Liu, D.; Bai, X. Hydroxysafflor yellow A suppresses angiogenesis of hepatocellular carcinoma through inhibition of p38 MAPK phosphorylation. Biomed. Pharmacother. 2019, 109, 806-814, http://doi.org/10.1016/j.biopha.2018.09.086.

48. Lei, H.; Ren, R.; Sun, Y.; Zhang, K.; Zhao, X.; Ablat, N.; Pu, X. Neuroprotective Effects of Safflower Flavonoid Extract in 6-Hydroxydopamine-Induced Model of Parkinson's Disease May Be Related to its AntiInflammatory Action. Molecules 2020, 25, http://doi.org/10.3390/molecules25215206.

49. Meng, Y.; Du, Z.; Li, Y.; Gao, P.; Song, J.; Lu, Y.; Tu, P.; Jiang, Y.; Guo, X. The synergistic mechanism of total saponins and flavonoids in Notoginseng-Safflower pair against myocardial ischemia uncovered by an integrated metabolomics strategy. Biomed. Pharmacother. 2020, 130, 110574, http://doi.org/10.1016/j.biopha.2020.110574.

50. Yang, J.; Wang, R.; Cheng, X.; Qu, H.; Qi, J.; Li, D.; Xing, Y.; Bai, Y.; Zheng, X. The vascular dilatation induced by Hydroxysafflor yellow A (HSYA) on rat mesenteric artery through TRPV4-dependent calcium influx in endothelial cells. J. Ethnopharmacol. 2020, 256, 112790, http://doi.org/10.1016/j.jep.2020.112790.

51. Wang, Y.; Shi, Y.; Zou, J.; Zhang, X.; Liang, Y.; Tai, J.; Cui, C.; Wang, M.; Guo, D. Network pharmacology exploration reveals a common mechanism in the treatment of cardio-cerebrovascular disease with Salvia miltiorrhiza Burge. and Carthamus tinctorius L. BMC Complementary Medicine and Therapies 2020, 20, 351, http://doi.org/10.1186/s12906-020-03026-y.

52. Tung, C.-L.; Hsieh, D.J.-Y.; Baskaran, R.; Ban, B.; Dung, T.D.; Ju, D.-T.; Viswanadha, V.P.; Day, C.H.; Yeh, Y.-L.; Huang, C.-Y. LPS-enhanced IGF-IIR pathway to induce H9c2 cardiomyoblast cell hypertrophy was attenuated by Carthamus tinctorius extract via IGF-IR activation. Environ. Toxicol. 2020, 35, 145-151, http://doi.org/10.1002/tox.22850.

53. Liu, Q.; Qu, H.-Y.; Zhou, H.; Rong, J.-F.; Yang, T.-S.; Xu, J.-J.; Yang, X.-L.; Lan, Z.-Z. Luhong Formula Has a Cardioprotective Effect on Left Ventricular Remodeling in Pressure-Overloaded Rats. Evid. Based Complement. Alternat. Med. 2020, 2020, 4095967, http://doi.org/10.1155/2020/4095967.

54. Jin, Y.; Yu, L.; Xu, F.; Zhou, J.; Xiong, B.; Tang, Y.; Li, X.; Liu, L.; Jin, W. Pharmacokinetics of Active Ingredients of Salvia miltiorrhiza and Carthamus tinctorius in Compatibility in Normal and Cerebral Ischemia Rats: A Comparative Study. Eur. J. Drug Metab. Pharmacokinet. 2020, 45, 273-284, http://doi.org/10.1007/s13318-019-00597-1.

55. Liu, F.; Wei, Y.; Yang, X.Z.; Li, F.G.; Hu, J.; Cheng, R.F. Hypotensive effects of safflower yellow in spontaneously hypertensive rats and influence on plasma renin activity and angiotensin II level. Yao xuе xиe bao= Acta pharmaceutica Sinica 1992, 27, 785-787.

56. Siow, Y.L.; Choy, P.C.; Leung, W.M.K.; Karmin, O. Effect of Flos carthami on stress-activated protein kinase activity in the isolated reperfused rat heart. Mol. Cell. Biochem. 2000, 207, 41-47, http://doi.org/10.1023/a:1017266628572.

57. Woo, W.S.; Shin, K.H.; Ryu, K.S. A survey of the action of KoreanAngelica plants on drug metabolism. Arch. Pharmacal Res. 1980, 3, 79, https://doi.org/10.1007/BF02855807.

58. Maljaars, J.; Romeyn, E.A.; Haddeman, E.; Peters, H.P.F.; Masclee, A.A.M. Effect of fat saturation on satiety, hormone release, and food intake. The American Journal of Clinical Nutrition 2009, 89, 1019-1024, http://doi.org/10.3945/ajcn.2008.27335.

59. Maljaars, P.W.J.; Symersky, T.; Kee, B.C.; Haddeman, E.; Peters, H.P.F.; Masclee, A.A.M. Effect of ileal fat perfusion on satiety and hormone release in healthy volunteers. Int. J. Obesity 2008, 32, 1633-1639, http://doi.org/10.1038/ijo.2008.166.

60. Wang, C.; Gao, Y.; Zhang, Z.; Chi, Q.; Liu, Y.; Yang, L.; Xu, K. Safflower yellow alleviates osteoarthritis and prevents inflammation by inhibiting PGE2 release and regulating NF- $\kappa \mathrm{B} / \mathrm{SIRT} 1 / \mathrm{AMPK}$ signaling pathways. Phytomedicine 2020, 78, 153305, http://doi.org/10.1016/j.phymed.2020.153305.

61. Hu, Z.-C.; Xie, Z.-J.; Tang, Q.; Li, X.-B.; Fu, X.; Feng, Z.-H.; Xuan, J.-W.; Ni, W.-F.; Wu, A.-M. Hydroxysafflor yellow A (HSYA) targets the NF- $\kappa$ B and MAPK pathways and ameliorates the development of osteoarthritis. Food Funct. 2018, 9, 4443-4456, http://doi.org/10.1039/c8fo00732b.

62. Qazi, N.; Khan, R.A.; Rizwani, G.H. Evaluation of antianxiety and antidepressant properties of Carthamus tinctorius L.(Safflower) petal extract. Pak. J. Pharm. Sci. 2015, 28, 991-995. 
63. Nakashima, Y.; Yuasa, S.; Hukamizu, Y.; Okuyama, H.; Ohhara, T.; Kameyama, T.; Nabeshima, T. Effect of a high linoleate and a high alpha-linolenate diet on general behavior and drug sensitivity in mice. J. Lipid Res. 1993, 34, 239-247.

64. Li, S.; Li, T.; Jin, Y.; Qin, X.; Tian, J.; Zhang, L. Antidepressant-Like Effects of Coumaroylspermidine Extract From Safflower Injection Residues. Front. Pharmacol. 2020, 11, 713, http://doi.org/10.3389/fphar.2020.00713.

65. Gu, S.; Ma, Y.; Ge, K.; Nie, R.; Wu, E.; Li, Y. Danshen-Honghua Ameliorates Stress-Induced Menopausal Depression in Rats. Neural Plast. 2018, 2018, 6589608, http://doi.org/10.1155/2018/6589608.

66. Abbasi-Maleki, S.; Mousavi, Z. Hydroethanolic extract of Carthamus tinctorius induces antidepressant-like effects: modulation by dopaminergic and serotonergic systems in tail suspension test in mice. Iranian journal of basic medical sciences 2017, 20, 1063, http://doi.org/10.22038/IJBMS.2017.9277.

67. Alaiye, A.; Kaya, E.; Pınarbaşlı, M.Ö.; Harmancı, N.; Yıldırım, C.; Dönmez, D.B.; Cingi, C. An Experimental Comparison of the Analgesic and Anti-Inflammatory Effects of Safflower Oil, Benzydamine $\mathrm{HCl}$, and Naproxen Sodium. J. Med. Food 2020, 23, 862-869, http://doi.org/10.1089/jmf.2019.0157.

68. Bosco, F.; Cidin, S.; Maceri, F.; Ghilli, M.; Roncella, M.; De Simone, L. An integrated approach with homeopathic medicine and electro-acupuncture in anaesthesiology during breast cancer surgery. Journal of pharmacopuncture 2018, 21, 126, http://doi.org/10.3831/KPI.2018.21.016.

69. Joanna, D.; Anna, J. Helenalin - A Sesquiterpene Lactone with Multidirectional Activity. Curr. Drug Targets 2019, 20, 444-452, http://doi.org/10.2174/1389450119666181012125230.

70. Priyanka, K.; Kumar, G.; Uttam Singh, B. Novel Herbal Topical Patch Containing Curcumin and Arnica montana for the Treatment of Osteoarthritis. Curr. Rheumatol. Rev. 2020, 16, 43-60, http://doi.org/10.2174/1573397115666190214164407.

71. Koriem, K.M.M.; Gad, I.B.; Nasiry, Z.K. Protective effect of Cupressus sempervirens extract against indomethacin-induced gastric ulcer in rats. Interdiscip. Toxicol. 2015, 8, 25-34, http://doi.org/10.1515/intox2015-0006.

72. da Silva Prade, J.; Bálsamo, E.C.; Machado, F.R.; Poetini, M.R.; Bortolotto, V.C.; Araújo, S.M.; Londero, L.; Boeira, S.P.; Sehn, C.P.; de Gomes, M.G.; Prigol, M.; Cattelan Souza, L. Anti-inflammatory effect of Arnica montana in a UVB radiation-induced skin-burn model in mice. Cutan. Ocul. Toxicol. 2020, 39, 126133, http://doi.org/10.1080/15569527.2020.1743998.

73. Asgary, S.; Rahimi, P.; Mahzouni, P.; Madani, H. Antidiabetic effect of hydroalcoholic extract of Carthamus tinctorius L. in alloxan-induced diabetic rats. Journal of research in medical sciences: the official journal of Isfahan University of Medical Sciences 2012, 17, 386.

74. Karimi-Sales, E.; Mohaddes, G.; Alipour, M.R. Chalcones as putative hepatoprotective agents: Preclinical evidence and molecular mechanisms. Pharmacol. Res. 2018, 129, 177-187, http://doi.org/10.1016/j.phrs.2017.11.022.

75. Lee, M.; Li, H.; Zhao, H.; Suo, M.; Liu, D. Effects of hydroxysafflor yellow A on the PI3K/AKT pathway and apoptosis of pancreatic $\beta$-cells in type 2 diabetes mellitus rats. Diabetes, metabolic syndrome and obesity: targets and therapy 2020, 13, 1097, http://doi.org/10.2147/DMSO.S246381.

76. Zhu, H.; Wang, X.; Pan, H.; Dai, Y.; Li, N.; Wang, L.; Yang, H.; Gong, F. The Mechanism by Which Safflower Yellow Decreases Body Fat Mass and Improves Insulin Sensitivity in HFD-Induced Obese Mice. Front. Pharmacol. 2016, 7, 127, http://doi.org/10.3389/fphar.2016.00127.

77. Thomas, S.S.; Cha, Y.-S.; Kim, K.-A. Effect of vegetable oils with different fatty acid composition on highfat diet-induced obesity and colon inflammation. Nutr. Res. Pract. 2020, 14, 425-437, http://doi.org/10.4162/nrp.2020.14.5.425.

78. Yan, K.; Wang, X.; Pan, H.; Wang, L.; Yang, H.; Liu, M.; Zhu, H.; Gong, F. Safflower Yellow and Its Main Component HSYA Alleviate Diet-Induced Obesity in Mice: Possible Involvement of the Increased Antioxidant Enzymes in Liver and Adipose Tissue. Front. Pharmacol. 2020, 11, 482, http://doi.org/10.3389/fphar.2020.00482.

79. Yan, K.; Wang, X.; Zhu, H.; Pan, H.; Wang, L.; Yang, H.; Liu, M.; Jin, M.; Zang, B.; Gong, F. Safflower yellow improves insulin sensitivity in high-fat diet-induced obese mice by promoting peroxisome proliferator-activated receptor- $\gamma 2$ expression in subcutaneous adipose tissue. Journal of Diabetes Investigation 2020, 11, 1457-1469, http://doi.org/10.1111/jdi.13285.

80. Liu, J.; Yue, S.; Yang, Z.; Feng, W.; Meng, X.; Wang, A.; Peng, C.; Wang, C.; Yan, D. Oral hydroxysafflor yellow A reduces obesity in mice by modulating the gut microbiota and serum metabolism. Pharmacol. Res. 2018, 134, 40-50, http://doi.org/10.1016/j.phrs.2018.05.012. 
81. Leslie, G.B. A pharmacometric evaluation of nine Bio-Strath herbal remedies. Medita 1978, 8, 3-19

82. Witzel, D.A.; Ivie, W.; Dollahite, J.W. Mammalian toxicity of helenalin, the toxic principle of Helenium microcephalum CD (smallhead sneezeweed). Am. J. Vet. Res. 1976, 37, 859-861.

83. Toxicology, I.J.O. Final report on the safety assessment of Arnica montana extract and Arnica montana. Int. J. Toxicol. 2001, 20, 1-11.

84. Hörmann, H.P.; Korting, H.C. Allergie acute contact dermatitis due to Arnica tincture self-medication. Phytomedicine 1995, 1, 315-317, http://doi.org/10.1016/S0944-7113(11)80009-7.

85. Herrmann, H.D.; Willuhn, G.; Hausen, B.M. Helenalinmethacrylate, a new pseudoguaianolide from the flowers of Arnica montana L. and the sensitizing capacity of their sesquiterpene lactones. Planta Med. 1978, 34, 299-304, http://doi.org/10.1055/s-0028-1097455.

86. Merfort, I. Arnika: Neue Erkenntnisse zum Wirkungsmechanismus einer traditionellen Heilpflanze. Complementary Medicine Research 2003, 10, 45-48, http://doi.org/10.1159/000071692.

87. Wang, Y.-p.; Guo, Y.; Wen, P.-s.; Zhao, Z.-Z.; Xie, J.; Yang, K.; Yang, Q.; Wang, J.-f.; Deng, X.-m. Three Ingredients of Safflower Alleviate Acute Lung Injury and Inhibit NET Release Induced by Lipopolysaccharide. Mediators Inflamm. 2020, 2020, 2720369, http://doi.org/10.1155/2020/2720369.

88. Qu, C.; Xu, D.-Q.; Yue, S.-J.; Shen, L.-F.; Zhou, G.-S.; Chen, Y.-Y.; Wang, X.-P.; Bai, J.-Q.; Liu, F.; Tang, Y.-P.; Zhao, B.-C.; Duan, J.-A. Pharmacodynamics and pharmacokinetics of Danshen in isoproterenolinduced acute myocardial ischemic injury combined with Honghua. J. Ethnopharmacol. 2020, 247, 112284, http://doi.org/10.1016/j.jep.2019.112284.

89. Özer, C.O.; Kılıç, B. Utilization of optimized processing conditions for high yield synthesis of conjugated linoleic acid by L. plantarum AB20-961 and L. plantarum DSM2601 in semi-dry fermented sausage. Meat Science 2020, 169, 108218, http://doi.org/10.1016/j.meatsci.2020.108218.

90. Schulz, V.; Hänsel, R.; Tyler, V.E. Rational Phytotherapy: A Physicians' Guide to Herbal Medicine; Springer Science \& Business Media, 1998.

91. Moghadam, B.K.; Gier, R.; Thurlow, T. Extensive oral mucosal ulcerations caused by misuse of a commercial mouthwash. Cutis 1999, 64, 131-134.

92. Seely, D.; Ennis, J.K.; McDonell, E.; Zhao, L. Naturopathic oncology care for thoracic cancers: a practice survey. Integr. Cancer Ther. 2018, 17, 793-805, http://doi.org/10.1177/1534735418759420.

93. MacGregor, J.T. Mutagenic activity of hymenovin, a sesquiterpene lactone from western bitterweed. Food Cosmet. Toxicol. 1977, 15, 225-227, http://doi.org/10.1016/s0015-6264(77)80393-3.

94. Stuppner, H.; Stuppner, H.; Rodriguez, E. A novel enol-pseudoguaianolide from Psilostrophe cooperi. Phytochemistry 1988, 27, 2681-2684, https://doi.org/10.1016/0031-9422(88)87043-2.

95. Koriem, K.M.M.; Arbid, M.S.; El-Gendy, N.F. The protective role of anise oil in oxidative stress and genotoxicity produced in favism. J. Diet. Suppl. 2016, 13, 505-521, http://doi.org/10.3109/19390211.2015.1119775.

96. Abudayyak, M.; Nath, E.Ö.; Özhan, G. Toxic potentials of ten herbs commonly used for aphrodisiac effect in Turkey. Turkish journal of medical sciences 2015, 45, 496-506.

97. Fernandes, C.R.; Turatti, A.; Gouvea, D.R.; Gobbo-Neto, L.; Diniz, A.; Ribeiro-Silva, A.; Lopes, N.P.; Garcia, S.B. The Protective Role of Lychnophora ericoides Mart. (Brazilian Arnica) in 1,2Dimethylhydrazine-Induced Experimental Colon Carcinogenesis. Nutr. Cancer 2011, 63, 593-599, http://doi.org/10.1080/01635581.2011.539310.

98. Hall, I.H.; Lee, K.H.; Starnes, C.O.; Sumida, Y.; Wu, R.Y.; Waddell, T.G.; Cochran, J.W.; Gerhart, K.G. Anti-inflammatory activity of sesquiterpene lactones and related compounds. J. Pharm. Sci. 1979, 68, 537542, http://doi.org/10.1002/jps.2600680505.

99. Viana, M.; Herrera, E.; Bonet, B. Teratogenic effects of diabetes mellitus in the rat. Prevention by vitamin E. Diabetologia 1996, 39, 1041-1046, http://doi.org/10.1007/BF00400652.

100.Reece, E.A.; Wu, Y.-K.; Wiznitzer, A.; Homko, C.; Yao, J.; Borenstein, M.; Sloskey, G. Dietary polyunsaturated fatty acid prevents malformations in offspring of diabetic rats. Am. J. Obstet. Gynecol. 1996, 175, 818-823, http://doi.org/10.1016/s0002-9378(96)80005-6. 